\title{
THE BENEFITS OF INTERNAL EGR TECHNOLOGY AS A TOOL TO IMPROVE THE Diesel Engine COLD START PERFORMANCE
}

\author{
Jorge Paulo Dantas De Araujo ${ }^{1}$, Flávio Augusto Levoto Cintra ${ }^{1.1}$, Ederson Sant'Ana Silva ${ }^{1.2}$ \\ MWM Motores Diesel
}

E-mails: jorge.dantas@ navistar.com.br, flavio.cintra@ navistar.com.br, ederson.silva@navistar.com.br

\begin{abstract}
Due to the evolution of legislation on pollutant emission levels, engine designs are facing new challenges, requiring the introduction of new technologies capable of reducing emissions with the minimum possible impact on engine efficiency, such as performance and fuel consumption. At the same time, the product competitiveness must be considered. It's no use having a product with a complex level of technology, if the cost to have this technology is prohibitive for the consumer. The EGR technology (Exhaust Gas Recirculation) is one of the most widely used and could be applied separately or used in conjunction with other technologies depending on the level of emissions to be achieved. This technology can be presented in different ways, being classified in internal EGR and external EGR. The external EGR is not yet suitable for small diesel engines in off-road applications due to the cost of the components used. The internal EGR is more feasible for this type of application, because it has great efficiency and does not add increment of components to the engine. Basically, internal EGR operation is achieved by modifying the valve train system, in this way, an event can be added to the intake valve during the exhaust cycle to increase the level of exhaust residue in the cylinder. This increase in the quantity of gases with reduced concentration of $\mathrm{O} 2$ and reduction of the concentration of $\mathrm{CO} 2$ contribute to reduce the average temperature of the combustion chamber, resulting in the reduction of NOx formation rates, among other benefits. But the internal EGR can also add value to other engine needs. For this reason, this article aims to describe the benefits found in the engine after the application of the EGR technology, but specifically in the first start engine results under conditions of low temperature. The application of this technology has simplified all the injection system calibration job with a significant gain in the start-up time and start-up smoke. The gains of Start-up time and start-up smoke in low-temperature conditions exceed 50\%, eliminating the need to apply cold start auxiliary systems in some cases.
\end{abstract}

\section{INTRODUCTION}

The control of gas emission levels legislation is one relevant drive to determine the level of technology to be applied in each engine, together with the other important factors as fuel consumption level, size of the engine, weight, application parameters and other specific customer necessities. In the case of internal combustion engines that work with the Diesel cycle, there are different emission standards (ON Highway or OFF Highway application) and 
these standards can be changed according to the requirements of each country where the equipment will be marketed.

In Brazil, the control of engine emissions is coordinated by CONAMA through the PROCONVE program. For Diesel cycle engines to be used in vehicular applications (ON Highway) this program is already in its 7th phase (PROCONVE P7), and for Diesel engines that equip machines for agricultural and construction equipment applications (Off Highway) the PROCONVE MAR1 (Agricultural and Construction Machines - Phase 1).

The MAR-1 is a standard that was built for the Brazilian market using a European standard that regulates OFF Highway engines to the emissions levels of its third phase (Stage IIIA). This emission standard started in 2015, and the implementation strategy was split by application segment that must be allowed according MAR-1 emission levels during 2015, 2017 and 2019 (three stages). Each step of the program is progressing according to figure 1.

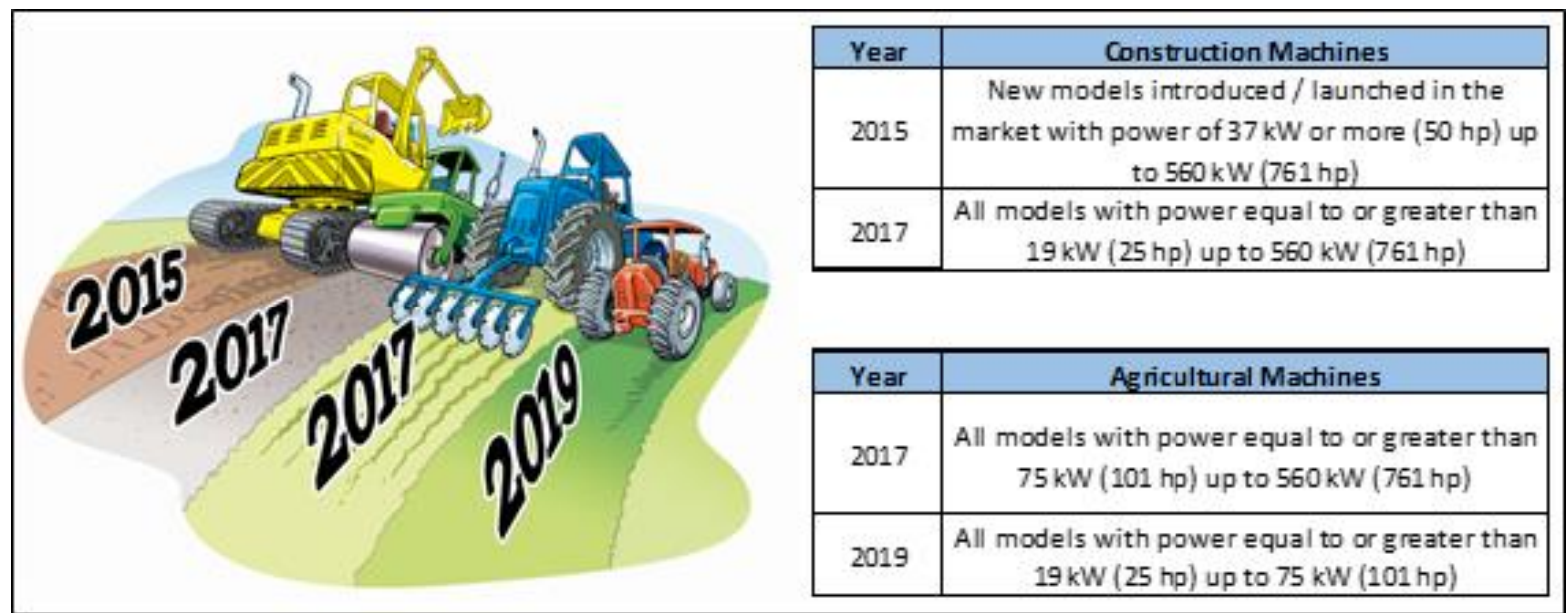

Figure 1 - MAR 1 Phases (source: MAR-1 Guide - ANFAVEA)

In addition to the division by application type, the MAR 1 program also created a second rule with different engine emission level limits per engine performance (power level). The values with the limits are according to table 1.

PROCONVE MAR-1 emission legislation for Construction and Agricultural Machinery have specific emissions levels per the power range (similar Stage IIIA)

\begin{tabular}{|cccc|}
\hline $\begin{array}{c}\text { Power } \\
(\mathbf{k W})\end{array}$ & $\begin{array}{c}\mathbf{C O} \\
(\mathbf{g} / \mathbf{k W h})\end{array}$ & $\begin{array}{c}\text { HC+NOx } \\
(\mathbf{g} / \mathbf{k W h})\end{array}$ & $\begin{array}{c}\mathbf{M P} \\
(\mathbf{g} / \mathbf{k W h})\end{array}$ \\
\hline $\mathbf{1 3 0} \leq \mathbf{P} \leq \mathbf{5 6 0}$ & 3,5 & 4,0 & 0,2 \\
$\mathbf{7 5} \leq \mathbf{P}<\mathbf{1 3 0}$ & 5,0 & 4,0 & 0,3 \\
$\mathbf{3 7} \leq \mathbf{P}<\mathbf{7 5}$ & 5,0 & 4,7 & 0,4 \\
$\mathbf{1 9} \leq \mathbf{P}<\mathbf{3 7}$ & 5,5 & 7,5 & 0,6 \\
\hline
\end{tabular}

Table 1 - MAR-1 Emissions Levels 


\section{GENERAL INFORMATION}

Based on the premise and requirements of the MAR-1 regulation, each engine manufacturer prepares by studying the technology to be used in the engine to achieve the MAR-1, and at the same time, the product must be competitive in cost, time to market, quality and simplicity. This is the only way to be a viable solution on all these aspects for the end customer.

Analyzing MAR-1 emission limits, it is clear a conclusion that when the engine power increases, the emission limits decrease. This is the base to determine the technologic package strategy for each engine according the power level.

Engines up to $37 \mathrm{~kW}$ (first line), the $\mathrm{HC}+\mathrm{NOx}$ limit is $7.5 \mathrm{~g} / \mathrm{kW} . \mathrm{h}$, and the PM limit is $0.6 \mathrm{~g} / \mathrm{kW} . \mathrm{h}$. Therefore, for this segment it is feasible to apply engines with a mechanical injection system, which has enough technology to meet these limits, and at the same time provide the cost competitiveness for the product.

For engines of the second power range, up to $75 \mathrm{~kW}$, injection systems can also be applied with mechanical pump, however, the systems need to have a higher level of complexity and functionalities due to the need to meet lower limits $(\mathrm{HC}+\mathrm{NOx}=4,7 \mathrm{~g} / \mathrm{kW} . \mathrm{h}$ and MP $=0.4 \mathrm{~g} / \mathrm{kW} . \mathrm{h})$.

In the third range (up to $130 \mathrm{~kW}$ ) there is a need to apply engines with an electronic injection system, or apply auxiliary systems in the engine to reduce emissions (such as EGR, for example) to comply with legislation $(\mathrm{HC}+\mathrm{NOx}=4.0 \mathrm{~g} / \mathrm{kW} . \mathrm{h}$ and $\mathrm{MP}=0.3 \mathrm{~g} /$ $\mathrm{kWh}$ ). One option in this segment would be the application of the combination between a mechanical pump injection system with the addition of internal EGR system. This type of solution is feasible for engines with moderate power density and for application in machines with lower level of technical complexity and must be aggressive in the cost / price point of view for the customer.

In the fourth range (up to $560 \mathrm{~kW}$ ) the decision to apply an electronic injection system is mandatory. In some cases, depending on the engine manufacturer's strategy regarding performance and fuel consumption the use of auxiliary systems to reduce emissions (EGR or SCR).

\subsection{Engine}

The engine submitted this case study fits the situation described in the MAR-1 third range. It is an MWM 4.10TCA engine with $88 \mathrm{~kW}$, where the technologic package strategy applied was a Mechanical pump injection system + Internal EGR system. The Specification details are given in figure 2. 


\begin{tabular}{|l|c|}
\hline \hline Engine & MWM 4.10TCA \\
\hline Emission Legislation & MAR.1 \\
\hline Configuration & In Line \\
\hline Displacement (I) & 4.3 \\
\hline Bore x Stroke (mm) & $103 \times 129$ \\
\hline Cylinder head configuration & $2 \mathrm{~V}$ \\
\hline Injection System & Mechanic \\
\hline Aspiration & Turbo + Intercooler \\
\hline Max Power (kW) & $88 \mathrm{~kW}$ \\
\hline Max Torque (N.m) & 490 N.m \\
\hline Injection System & VE Pump (Bosch) \\
\hline EGR System & Yes (AVL TINER $\left.{ }^{\circledR}\right)$ \\
\hline
\end{tabular}

Figure 2 - Engine Detail / Configuration

\subsection{Internal EGR System}

Simply put, exhaust gas recirculation (EGR) is the method by which a portion of engine's exhaust is returned its combustion chamber via inlet system (see Figure 3). This method is designed to extract heat from the combustion process, thus lowering its temperature and reducing NOx. This method also involves displacing some of the oxygen inducted into the engine with its fresh charge air, thus reducing the rate of NOx formation (Majewski and Khair, 2006).

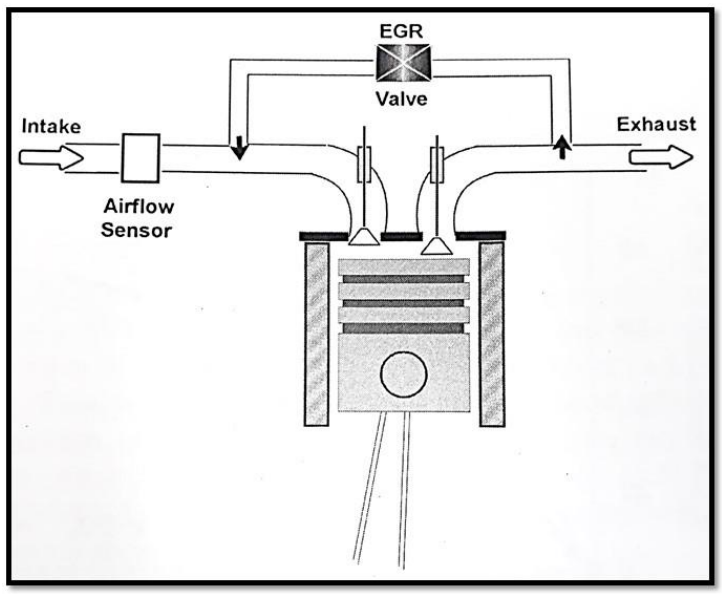

Figure 3 - Schematic representation of an EGR system for heavy-duty diesel engine (Majewski and Khair, 2006)

Basically, the EGR system can be classified in two different concepts: External EGR system or Internal EGR System. In the external EGR system there is an independent system (outside of the engine) with pipes, a valve and in some cases a cooler that is responsible to deliver the exhaust gas to the combustion chamber. In the case of the Internal EGR operation is achieved by modifying the valve train system, in this way, an event can be added to the intake valve during the exhaust cycle to increase the level of exhaust residue in the cylinder. 
Internal EGR is a very cost-effective technology for in-cylinder nitrogen oxides emission reduction and presents some advantages compared to external EGR solution (Gasparini, 2015).

- No external pipes (use to be expensive);

- No EGR control system;

- Low sensitiveness to exhaust backpressure;

- Low sensitiveness to fuel sulfur content;

- No additional maintenance;

- Cost and packaging advantages;

- Excellent cold start and warm-up characteristics;

The AVL TINER ${ }^{\circledR}$ internal EGR working principle is basic a pre-lift of the intake vale where the exhaust and intake valves open during the exhaust stroke. Hence a certain amount of exhaust gas is delivered towards the intake ports and re-aspirated together with fresh air during the next intake stroke event, as see in figure 4 (Gasparini, 2015).

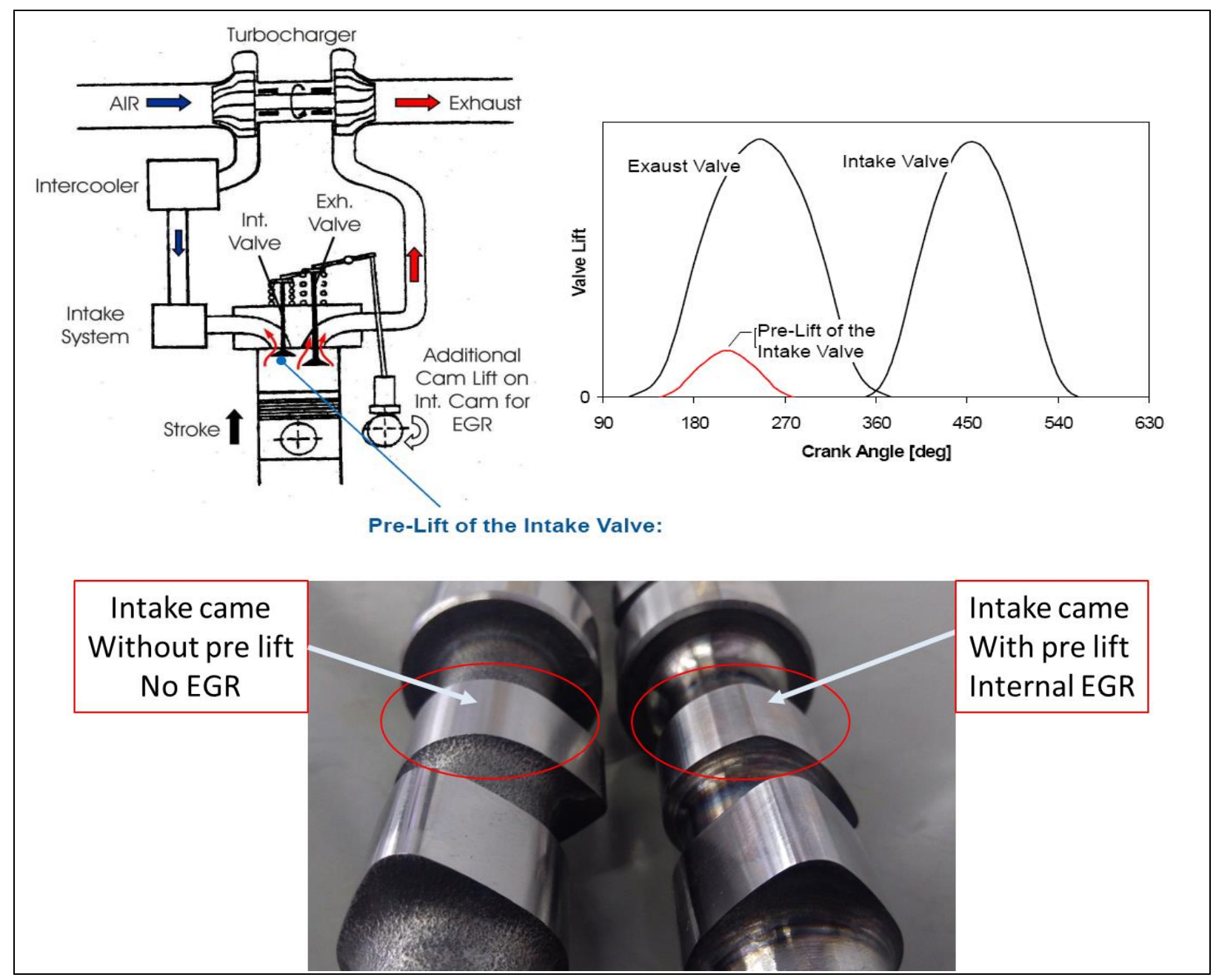

Figure 4: Internal EGR working principle (MWM / AVL report, 2014) 


\subsection{Engine calibration process}

There is a specific procedure to develop a combustion engine that will work with a mechanical injection system. This procedure can be changed depending of the injection pump model / supplier. Make part of the process analyze the injection system in the engine assembled in a dynamometer and in parallel analyze the same in a specific injection system bench test. These activities are necessary to speed up the process and fix all the engineering issues before the engine homologation / start of production. In the figure number 5 is possible to see this process in a simplified way.

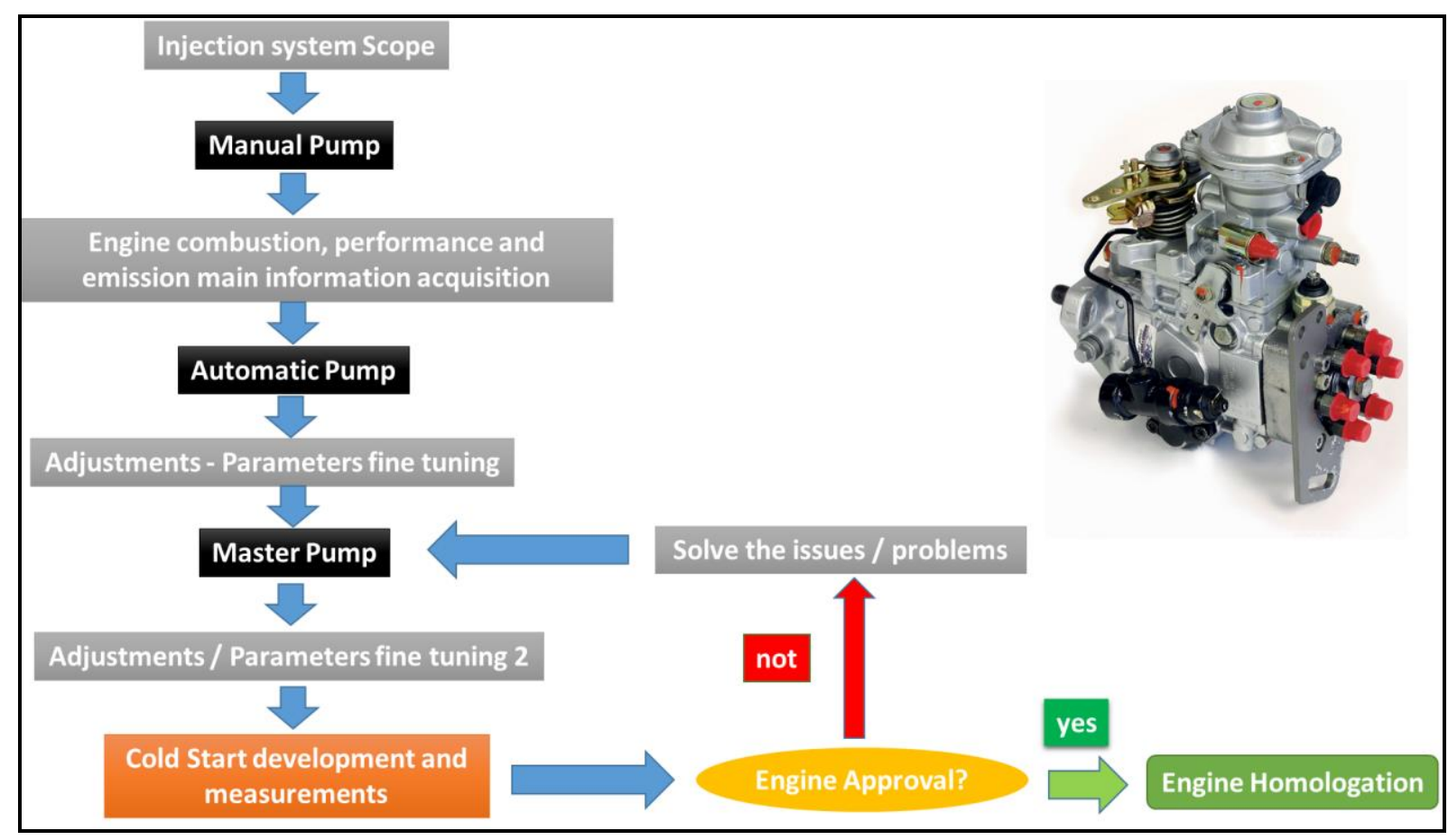

Figure 5 - Diesel Engine / Mechanical pump injection system development process

In the figure 5 is possible to see that the cold start process is realized in the final phase of the development job. It is important to understand also that the mechanical injection system does not provide many resources to calibrate the cold start condition without change other engine characteristics that were calibrated before the cold start job. If the cold start result is not in an accordance with the project scope, it will be necessary a rework to improve the cold start performance and consequently will be necessary a looping to analyze if all the other pump and engine parameters still ok after the cold start changes.

Other important parameter that need to be evaluated during the Diesel engine cold start capacity development is the white smoke level. The white smoke is a common phenomenon during the first engine start in the cold condition. During the first start, the Diesel fuel have a delay to start the combustion process due the low temperature. When the combustion starts, there are a lot of Diesel inside the combustion chamber and some part of this fuel do not burn in the correct way, becoming white smoke. 
The level of white smoke could be optimized working in the engine efficiency (start of injection, compression rate, nozzle flow quantity or flow angle and the fuel quantity). It is important to mention that changing the engine efficiency could compromise other engine parameters as much as performance, fuel consumption and emissions. There is a tradeoff between all these characteristics that need to be considered before take the final decision about change the hardware to optimize the white smoke level.

In the photographic comparison below (figure 11 and 12) it is possible analyze the influence of Internal EGR System in the result of white smoke. During the cold start process, when is applied an I-EGR, each cylinder start to receive air from the all the other cylinders. This air just passed for a compression process inside of the engine, increasing the temperature inside of all cylinders. This phenomenon is sufficient to speed up the Diesel capacity to start the burn with more efficiency, reducing the start time and consequently, the level of white smoke.

\section{BENCH TEST RESULTS}

Both engines were tested in a cold chamber bench test, with similar ambient temperature and same soak time (period inside of the cold chamber before the engine start), around 12 hours. See figure 6.

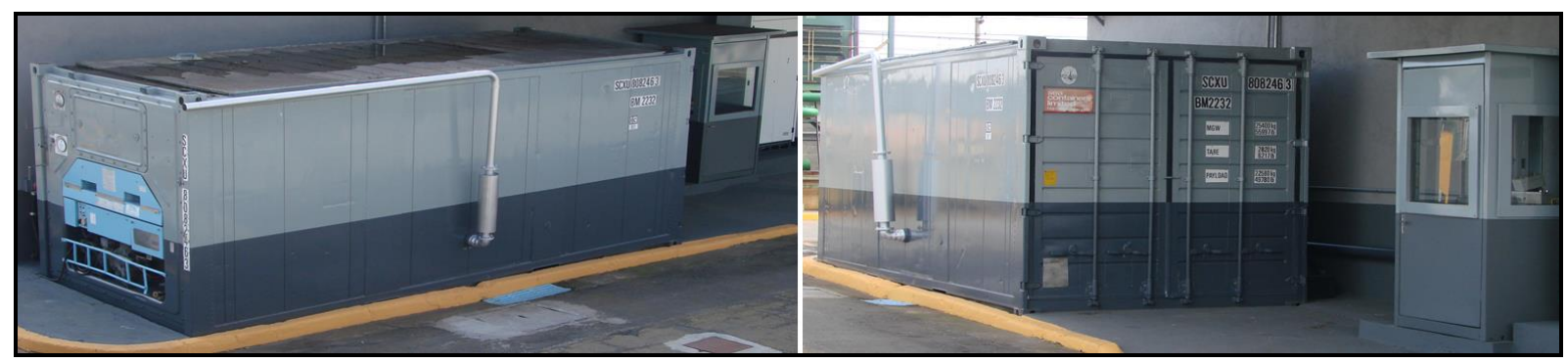

Figure 6 - MWM Cold Start Bench Test (Capacity until -25 ${ }^{\circ} \mathrm{C} / 2$ Engines in parallel)

The Propose of this test is analyze the cold start capacity (time necessary to start the engine combustion) and analyze also the white smoke produced during first start.

Below is demonstrated the comparison between 2 engines ( $\mathrm{A} \times \mathrm{B}$ ). The engine " $\mathrm{A}$ " represents the base line condition (with the internal EGR system applied) and the engine "B" represent the same engine but without the Internal EGR system (in this case, was assembled a camshaft that does not have the pre-lift in the intake came (figure 4).

In the acquisition data from the figures $7,8,9$ and 10 is possible to compare the start time performance (engine " $A$ " versus engine " $B$ ") in two different conditions of ambient temperature $\left(0^{\circ} \mathrm{C}\right.$ and $\left.-5^{\circ} \mathrm{C}\right)$. 


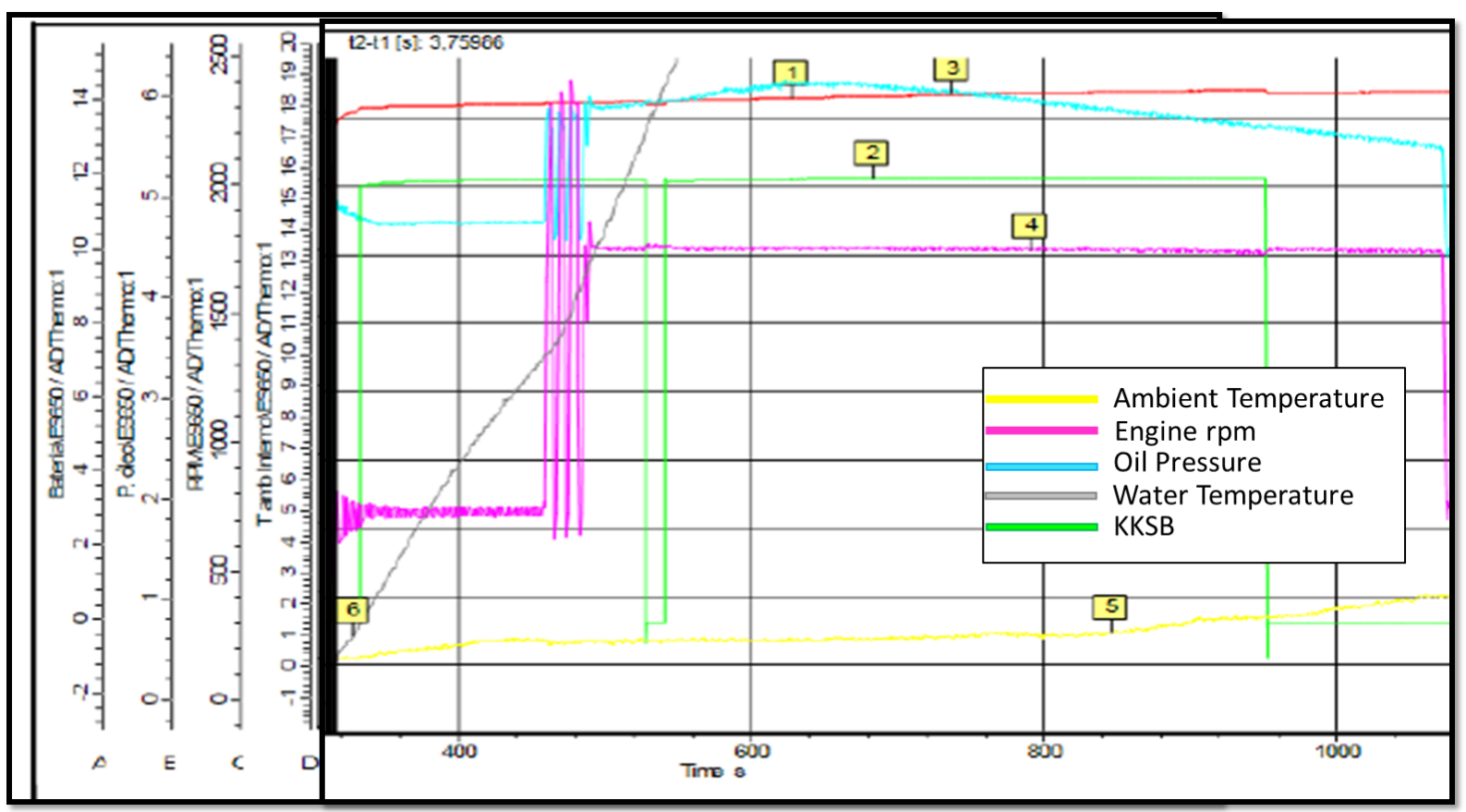

Figure 7 - Cold test data acquisition / Engine "A" (with Internal EGR system) / Result: Engine Start up after 3,8 Sec / $1^{\text {st }}$ attempt / Ambient temperature $\underline{0^{\circ} \mathrm{C}}$ (inside of the cold chamber)

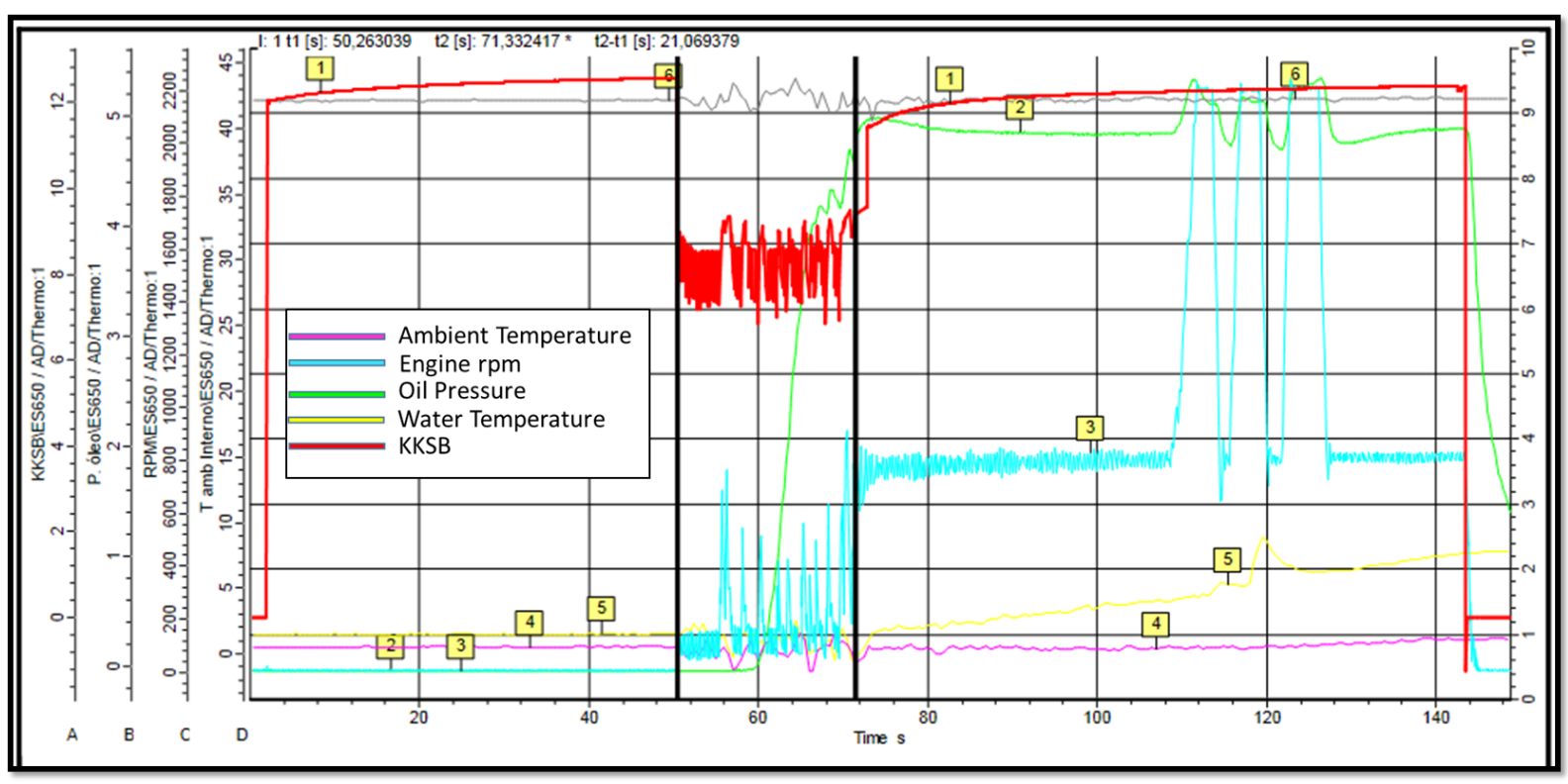

Figure 8 - Cold test data acquisition / Engine "B" (without Internal EGR system) / Result: Engine Start up after $21 \mathrm{Sec} / 1^{\text {st }}$ attempt / Ambient temperature $\underline{0^{\circ} \mathrm{C}}$ (inside of the cold chamber) 


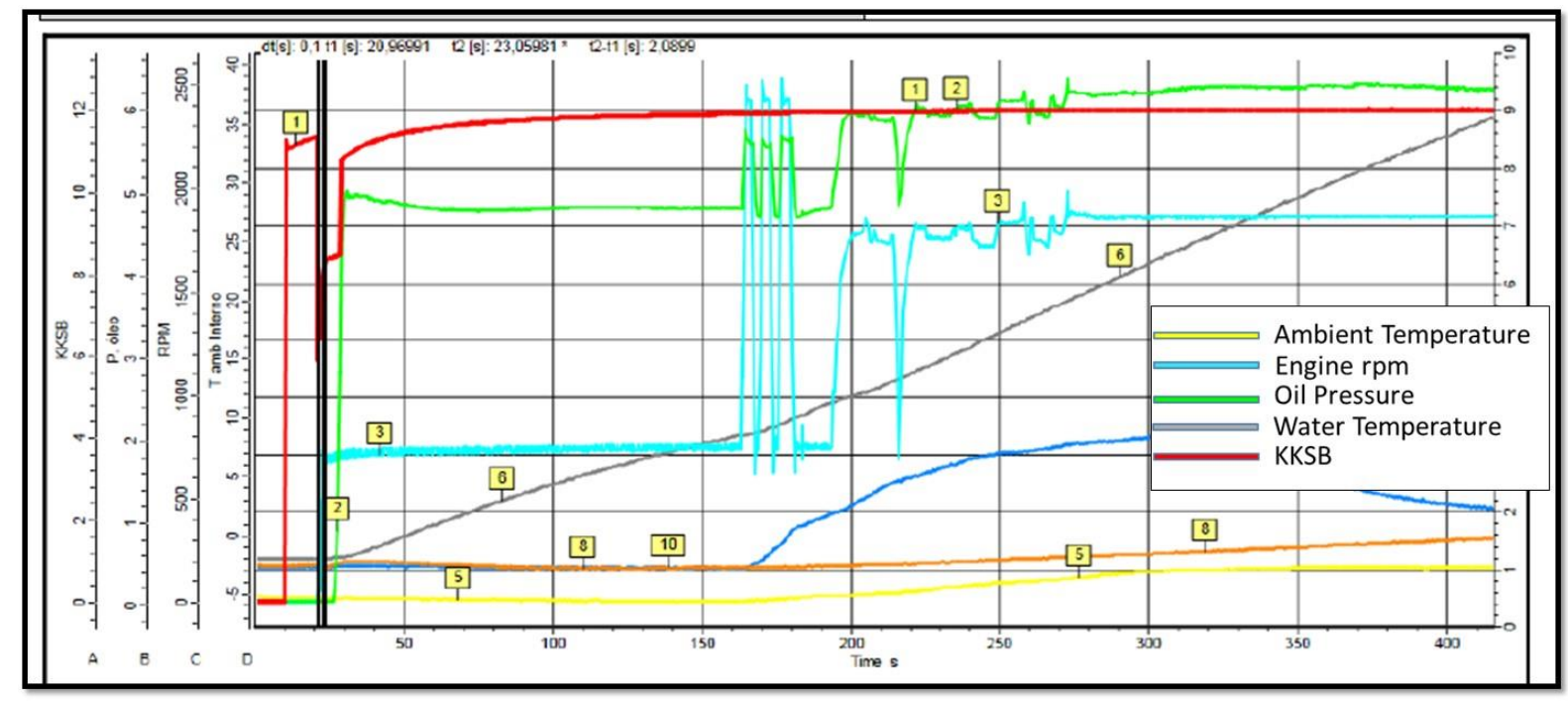

Figure 9 - Cold test data acquisition / Engine "A" (with Internal EGR system) / Result: Engine Start up after 2.1 Sec / $1^{\text {st }}$ attempt / Ambient temperature $-5^{\circ} \mathrm{C}$ (inside of the cold chamber).

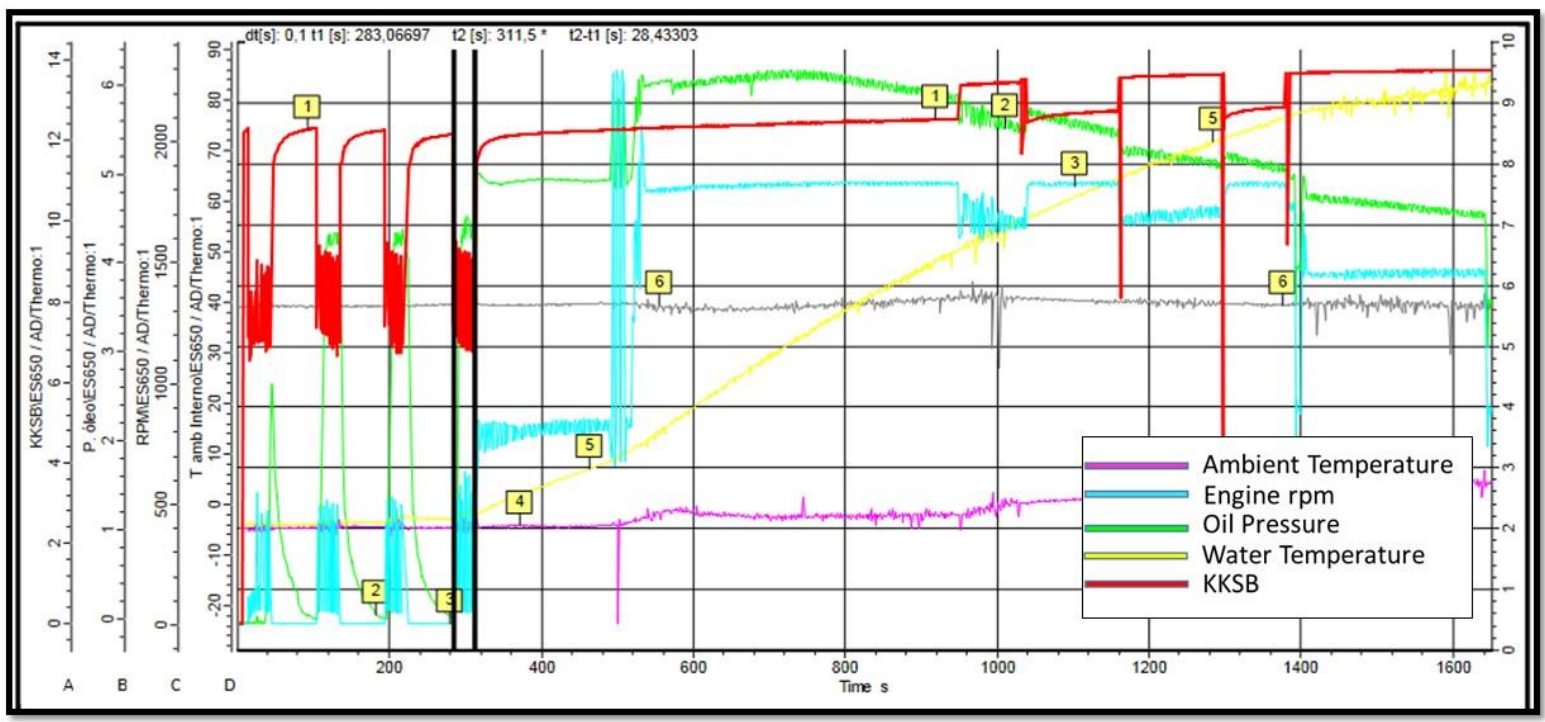

Figure 10 - Cold test data acquisition / Engine "B" (without Internal EGR system). Result: Engine Start up after $28 \mathrm{Sec} / 4^{\text {th }}$ attempt / Ambient temperature $-5^{\circ} \mathrm{C}$ (inside of the cold chamber). 


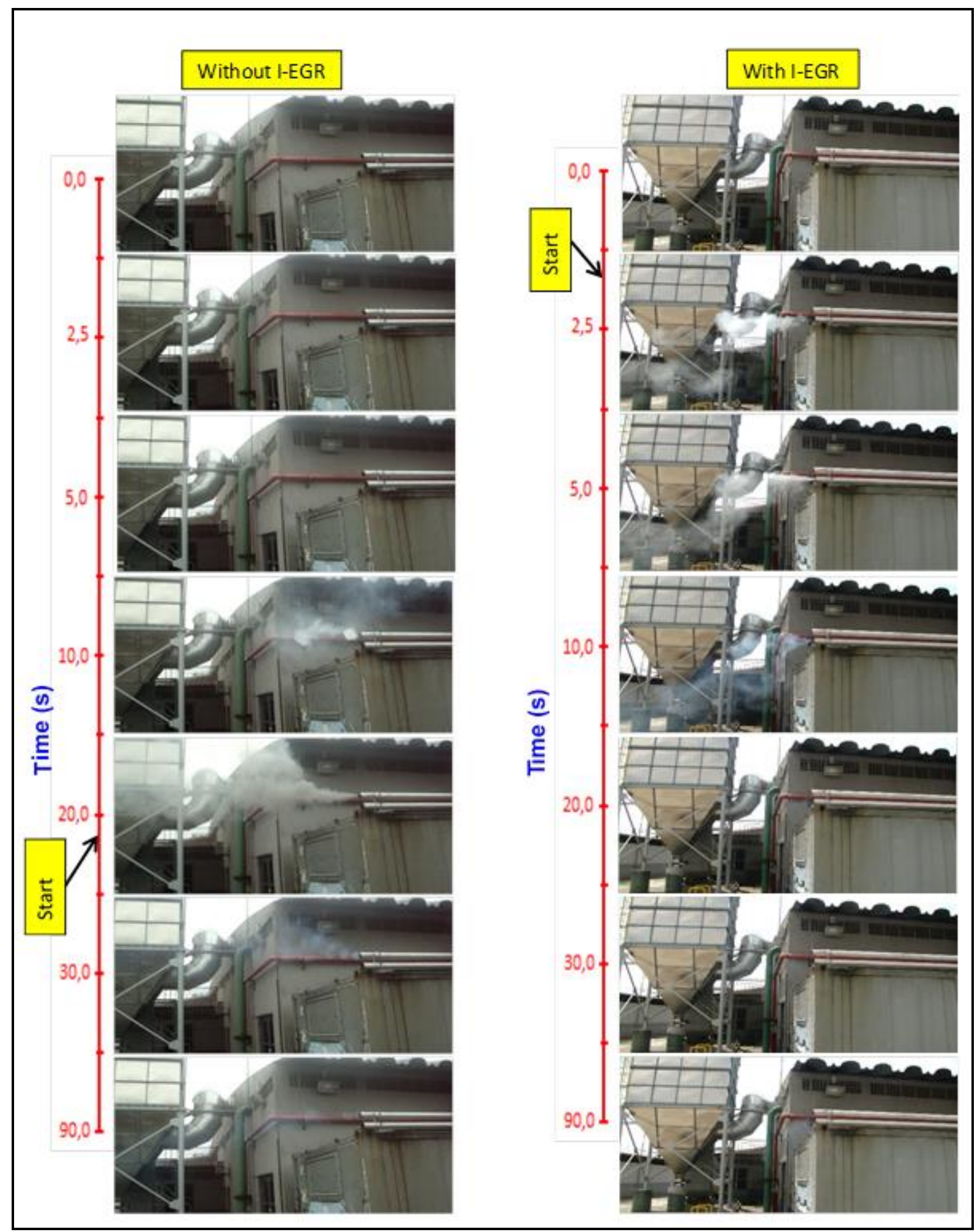

Figure 11 - White smoke level comparison between - Engine " $A$ " versus Engine " $B$ " Ambient Temperature: $\underline{0^{\circ} \mathrm{C}}$ 


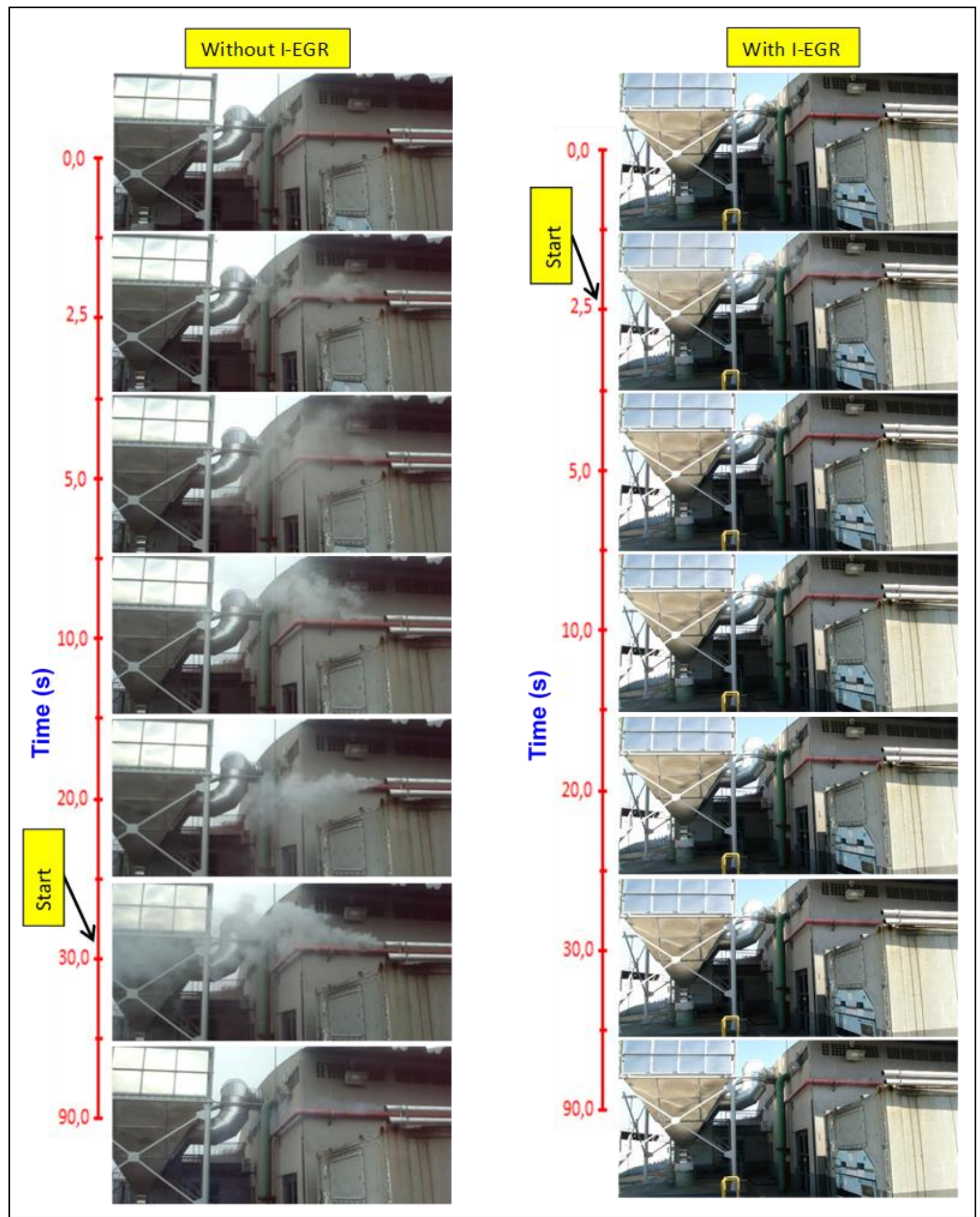

Figure 12 - White smoke level comparison between - Engine " $A$ " versus Engine "B" Ambient Temperature: $\underline{-5^{\circ} \mathrm{C}}$ 


\section{CONCLUSION}

The comparison between the engines "A" (with I-EGR) versus "B" (without IEGR) show that the I-EGR package provide a very good advantage in terms of start time and white smoke performance. The engine with I-EGR starts in 3,8 seconds $\left(1^{\text {st }}\right.$ attempt $) @ 0^{\circ} \mathrm{C}$ of ambient temperature and 2,1 seconds $\left(1^{\text {st }}\right.$ attempt $) @-5^{\circ} \mathrm{C}$ of ambient temperature. The hardware was not sensitive to decrease the start time performance due the temperature change $\left(0^{\circ} \mathrm{C}\right.$ to $\left.-5^{\circ} \mathrm{C}\right)$, what is a fantastic result.

In the opposite side, the engine that do not have the I-EGR package is very sensitive in terms of start time performance and white smoke level. The decrease of the ambient temperature was determinant for the loss of performance in start time and white smoke level. The engine without I-EGR starts in 21 seconds @ $0^{\circ} \mathrm{C}$ of ambient temperature ( $1^{\text {st }}$ attempt) and 28 seconds @ $-5^{\circ} \mathrm{C}$ of ambient temperature ( $4^{\text {th }}$ attempt). This engine would be disapproved with these results and in this hypothesis, it would be necessary a change in the calibration of the injection pump or change base engine components to improve the cold start performance, and consequently a looping in the calibration process, losing time and increasing the cost of the project, with a risk to not fix $100 \%$ the problem.

\section{REFERENCES}

[1] MAJEWSKI, W. Addy; KHAIR, Magdi K. Diesel Emissions and Their Control. USA: SAE International, 2006.

[2] GASPARINI, Ricardo; CINTRA, Flavio. IMPLEMENTATION OF AN INTERNAL EGR TECHNOLOGY IN A MDD ENGINE TOWARDS MEETING MAR-I USING NUMERICAL

Simulations, SAE; Brazil, 2015.

[3] ANFAVEA, MAR 1 Guide. Available in http://www.anfavea.com.br/docs/cartilha_mar1.pdf. Acess in May, 20, 2017.

\section{DEFINITIIONS / ABBREVIATIONS}

$\begin{array}{ll}\mathrm{CO}: & \text { Oxide of Carbon } \\ \mathrm{CO}_{2}: & \text { Dioxide of Carbon } \\ \mathrm{ECM}: & \text { Electronic Control Module } \\ \text { EGR: } & \text { Exhaust Gas Recirculation } \\ \text { I-EGR: } & \text { Internal Exhaust Gas Recirculation } \\ \mathrm{HC}: & \text { Hydrocarbon } \\ \mathrm{NO}_{\mathrm{x}}: & \text { Oxides of Nitrogen } \\ \text { PM: } & \text { Particulate Matter } \\ \text { SCR: } & \text { Selective Catalytic Reduction }\end{array}$




\section{CONTACT INFORMATION}

Jorge Paulo Dantas De Araujo

Email: jorge.dantas@ navistar.com.br

Tel. +55 11 3882-3777

Flavio Augusto Levoto Cintra

Email: flavio.cintra@ navistar.com.br

Tel.+55 $113882-3290$

\section{Ederson Sant'Ana Silva}

Email: ederson.silva@ navistar.com.br

Tel. +55 $113882-3716$ 